\title{
Satellite-linked tsunami warning to avoid Pacific disasters
}

Washington \& Tokyo

Although tsunami is a Japanese word, and the phenomenon, commonly known as a tidal wave, has killed more people and done more damage in Japan than anywhere else, all Pacific nations are at risk from its destructive power. Warning systems of varying sophistication exist in some, but many of the poorer or more remote areas, such as the Philippines and the west coast of South America, are largely unprotected.

Now a new system, developed by the US National Oceanic and Atmospheric Administration (NOAA), in cooperation with the Chilean authorities, is operating in Valparaiso, Chile, and may soon guard vulnerable sites around the Pacific rim for as little as $\$ 20,000$ per location.

Unlike the movie versions, real tsunamis are not walls of water several storeys high. Their height is modest, a metre or two at most, but they can be 100 miles long, and travel at 600 miles per A scene of devastation on the shore of Aomori
Prefecture after the Japan Sea tsunami of 1983.

hour. On reaching the shore, the huge volume of water can flood harbours and overwhelm coastal villages in minutes, throwing fishing boats and even concrete breakwaters inland.

Tsunamis are caused by submarine earthquakes (occasionally volcanoes), and most of the destruction occurs within 200 miles of the original disturbance. Seismic p-waves travel at 400 miles per minute, which gives less than 20 minutes warning of an impending tsunami for those places most at risk.

The present Japanese warning system has advanced seismometers around the country, which feed their information to six regional centres for analysis and the issuance of tsunami warnings, graded according to the severity of the threat. A drawback is the time taken for warnings to be sent out: in May 1983 a 'great tsunami' warning was not issued until 13 minutes after the original earthquake. Over one hundred people died.

The Japanese system also suffers from a dependence on complex technology. Where adequate maintenance cannot be guaranteed or where communications are fragile (especially after an earthquake), a simpler and more robust system is needed. On these criteria, the Foreign Disaster Assistance section of the US Agency for International Development (AID) approached NOAA, which already operates a Pacific warning system based in Hawaii. NOAA in turn began a collaboration with the Chileans to improve existing tsunami protection plans at Valparaiso.

The new system relies on a simple accelerometer, rather than a seismometer, set up to trigger when an earthquake above magnitude 7.0 on the Richter scale occurs. An alarm is sent to a geostationary NOAA satellite, which relays the signal to a ground station in Wallops Island, Virginia. There the emergency routine goes into action, and a general warning is issued via the satellite, back to the ground station.

In repeated tests carried out over the past year, a prototype system at Valparaiso has worked with 98 per cent reliability and with a response time of about one minute.

The system has been developed under the guidance of Dr Eddie Bernard of

\section{IMAGE UNAVAILABLE FOR COPYRIGHT REASONS}

A car stranded on the rocks after the Japan Sea tsunami of May 1983 in Aomori Prefecture, northwest Honshu, Japan.

NOAA, who says its virtues are simplicity, low cost and independence. A ground station consisting of an accelerometer, a small personal computer and the receiving and transmitting devices can be constructed from off-the-shelf components for about $\$ 20,000$, with running costs about one tenth of that amount per year.

Each ground station is self-powered, and is not connected except by satellite to any other equipment. What happens at each site when the warning is issued is entirely in the hands of local authorities, although NOAA and AID have helped in setting up evacuation plans.

Destructive tsunamis are rare, occurring about once a year throughout the Pacific region. It is a difficult matter, says Bernard, deciding at what level the system should trigger; not all big earthquakes cause tsunamis, and if false alarms were issued too often, people would become inured to them. The designers of NOAA's system have erred on the side of caution, hoping that the first years of operation will allow refinement of the ground station set- up. David Lindley \& David Swinbanks

\section{Spread of 'socialist jaundice' worsens in Uzbekistan}

London

THE Uzbek Academy of Sciences and the Moscow Main Institute of Virology have launched a crash research programme into a new form of hepatitis reported to be of epidemic proportions in the republic.

According to Dr Sanasyr Shavakhavov, deputy minister of health and chief public health officer for Uzbekistan, the virus strikes for the most part people of working age, and has a particularly severe effect on pregnant women. The infection spreads at an "explosive" rate, he told a reporter from Pravda Vostoka last week. Clinical trials have, however, already begun in Tashkent of a new gamma globulin, developed in Moscow, which it is hoped will prove effective against the disease. Until recently, hepatitis - known colloquially in Eastern Europe as 'socialist jaundice' - was not openly mentioned in the Soviet media, as discussion of it was viewed as hostile criticism of the Soviet health service. The glasnost campaign has revealed, that in Moldavia, for example, the hepatitis-B virus has been found in 13 per cent of the population, and in some regions as many as 23 per cent. In many cases, it is officially admitted, patients have been infected with the virus while in hospital for surgery, due to cross-infection from contaminated syringes.

The new Uzbek hepatitis (which may possibly be identical with the "non-A nonB' form reported elsewhere) has triggered mass quarantine in which what Shavakhavov has described as "the most diverse ministries and departments in Uzbekistan" are involved. Travel beyond the boundaries of the republic is subject to strict public health control, and all vegetable and fruit produce sent out of the republic is monitored. All large gatherings, assemblies or meetings are discouraged, a decision which will prove a further impediment to the current attempts by the Crimean Tartars, resident in Uzbekistan, to organize a campaign for the right to return to their historic homeland.

Vera Rich 